\title{
The Orff approach in the professional lives and practices of teachers in the Aotearoa/New Zealand school context
}

\section{Millie Locke}

\begin{abstract}
This doctoral research investigated issues concerned with the application of the Orff approach to music education in the Aotearoa New Zealand school context. The author brought to the study an indepth knowledge of the Orff approach as a result of engagement with both the practice and theory of the Orff approach over a 15-year span of teaching music in a state primary school. She noted the scarcity of contemporary studies that systematically investigate the potentialities and constraints of the Orff approach, particularly in the New Zealand context.
\end{abstract}

Drawing upon a praxial philosophy, this project considered from a scholarly perspective the way in which engagement with the Orff approach impacted on the professional lives of nine teachers, all of whom had adapted this approach to their respective school settings. Taking into account the widely acknowledged inconsistency in the quality, or even existence, of music programmes in the state school system, this study sought to investigate the impact of professional learning in the Orff approach upon the provision of music education programmes in schools.

In epistemological terms, this study was qualitative in its interest in the participants' experiences and how they interpreted them. The nine participant teachers, had all undertaken, over a period of three or more years, a number of courses offered by Orff New Zealand Aotearoa (ONZA). Using multiple case studies, this project aimed to gain access to the wealth of knowledge and know- how that teachers develop in their everyday work lives. Mixed methods in the form of questionnaires, observations and interviews and a focus group discussion were used to gather data. Findings emerging from a quantitative analysis of the questionnaire responses were used to illuminate and triangulate with findings from other data, which were analysed thematically.

A recursive approach to analysis of the data produced findings which indicated that the Orff approach impacted upon how teachers thought about what it means to do music, to be a musician and to teach music. These findings are illustrated in individual case studies, which offer a richly textured description of the impact of the Orff approach upon these teachers and their respective classroom practices.

Although all participants described the approach as making an impact in broadly similar terms upon their thinking, the practices observed and reported on in their classroom settings were varied in terms of their choice of materials activities and purposes. Findings of a more generally thematic nature indicate that the professional learning that occurred for these teachers yielded significant sources of self-efficacy, which in turn impacted upon the formation of professional identity formation. The

Wilf Malcolm Institute of Educational Research, Faculty of Education, University of Waikato, Hamilton, New Zealand ISSN: 2382-0373

Permanent Research Commons link to full thesis: http://hdl.handle.net/10289/9990 (pp. 109-110) 
construction of teaching as an artistic endeavour emerged as a characteristic of the understanding and application of the Orff approach in the New Zealand setting.

This study contributes to the understanding of the impact of the Orff approach upon teachers' lives and work. In particular, it illustrates some of the consequences of the construction of music as a form of embodied behaviour available to all people and offers some examples of specific ways in which educational practices can reflect this belief.

This study engages respectfully with the work of teachers 'on the ground' at a time when calls for so called 'accountability', through ever-increasing bureaucratic systems of standards-based assessment and teacher monitoring. To a small extent, it offers a voice for these teachers and the work they do in enabling success for all in music for their pupils.

For a greater understanding and to enable critical interrogation of music education in Aotearoa New Zealand, studies which are focused on classroom practice and ask the question: 'What is the construction of music and of teaching and/or of education that lies beneath or pervades practice?' needs to be asked in order to continue the debate regarding the role and efficacy of music education practices in New Zealand schools. 